\title{
Improvement of the Decolorization of Azo Dye (Direct Red 81) by Immobilized Cells of Bacillus pumilus and Free Cells of Aspergillus clavatus in Textile Waste Waters
}

\author{
Walaa A. Al-Shareef ${ }^{1 *}$, Salwa S.I. Afifi' ${ }^{2}$, Mohamed A. Ramadan ${ }^{3}$ and Nesma R. Sakr ${ }^{1}$ \\ ${ }^{1}$ Microbiology and Immunology Department, Faculty of Pharmacy, October 6 \\ University, Giza \\ ${ }^{2}$ Microbiology and Immunology Department, Faculty of Pharmacy-Girl, Al-Azhar \\ University, Cairo \\ ${ }^{3}$ Microbiology and Immunology Department and Biotechnology Centre, Faculty of Pharmacy, \\ Cairo University, Cairo \\ *Corresponding author
}

\begin{tabular}{|l|}
\hline Ke y w o r d s \\
$\begin{array}{l}\text { Biodegradation, } \\
\text { Decolorization, Bacillus } \\
\text { pumilus, Aspergillus } \\
\text { clavatus, DR81, } \\
\text { Immobilization, and } \\
\text { wastewaters }\end{array}$ \\
\hline Article Info \\
\hline $\begin{array}{l}\text { Accepted: } \\
12 \text { April } 2018 \\
\text { Available Online: } \\
10 \text { May } 2018\end{array}$ \\
\hline
\end{tabular}

A B S T R A C T

In this study, the effluent wastewater samples collected from dyestuff industrial area have been examined for biological treatment. The rate of decolorization was assessed using spectrophotometer at $508 \mathrm{~nm}$ and the percentage of decolorization was ascertained. The metabolites of Direct Red 81 (DR81) obtained after biodegradation were determined by HPLC. In order to improve the decolorization process, the effect of process factors like $\mathrm{pH}$, temperature, agitation and dye wastewater concentration on dye decolorization was studied. From the results, a potential bacterium and fungus isolates, namely, Bacillus pumilus and Aspergillus clavatus, respectively, have been isolated and identified from dyestuff industrial area for the decolorization of DR81. After 5 days of incubation period with Bacillus pumilus and Aspergillus clavatus, the bacterium showed $17 \%$ of decolorization, while the fungus showed $95 \%$ of decolorization at a dye concentration of $100 \mathrm{mg} / \mathrm{L}$ at $30 \pm 0.2^{\circ} \mathrm{C}$ under aerobic processes. Mixed culture of Bacillus pumilus and Aspergillus clavatus were found to decolorize $88 \%$ of DR 81 after 5 days of incubation. Bacillus pumilus showed the best extent degradation of DR81 (97\%) when supplemented with yeast extract after 5 days of incubation. Furthermore, supplemented cells of Aspergillus clavatus with yeast extract showed 99\% of DR81 while it showed $98 \%$ of when supplemented with glucose, and non-supplemented cells showed $95 \%$ of degradation after 5 days of incubation too. Free cells of Aspergillus clavatus showed $95 \%$ decolorization of DR81 after 5 days of incubation compared to immobilized cells (74\%) on activated charcoal $(20 \mathrm{~g} / \mathrm{L})$ in mineral salt medium (MSM), while immobilized cells of Bacillus pumilus on kaoline $(20 \mathrm{~g} / \mathrm{L})$ showed $71 \%$ decolorization of DR81 compared to free cells $(17 \%)$. Therefore, the potential of these microbial isolates can be exploited for the removal of residual dyes from the industrial wastewater for environmental cleanup and restoration of the ecosystem. 


\section{Introduction}

Azo dyes represent a major group of aromatic chemical compounds which are extensively used in textile dyeing and many other industries. Azo dyes are used widely for dyeing purposes and constitute about $70 \%$. Therefore, azo dyes are the most important and largest group of synthetic colorants released into the environment (Lade et al., 2015; Kadam et al., 2011). They are classified as reactive, direct, disperse, acid, basic and vat dyes (Sathian et al., 2013). Among these various types, DR81 dyes represent more than half of the dyes present in the pulp and textile industries (Walger et al., 2018) and they usually contain at least one azo group and some sulfonic acid groups thus making them water soluble. They have the same chromophore $\mathrm{N}=\mathrm{N}$ and different auxochromes groups as $\mathrm{NH}_{2}$ and $\mathrm{OH}$ (Olaganathan and Jamila 2010).

The releasing of such dyes in natural ecosystem results into azo group conversion to aromatic amines which could result in a toxic impact on aquatic life and even carcinogenic and mutagenic effect on humans. Therefore, wastewater containing such dyes must be treated before its release into the receiving water bodies. In addition, these dyes considered to be bio-recalcitrant contaminants which released to the environment during manufactures in the food, textile, and papermaking industries (Kim et al., 2007). Hence, researchers have focused on the biological treatment of the dye wastewaters as the best alternative method when compared with physiochemical methods (Surwase et al., 2013). The cost-effectiveness, ecological sociability of biological systems, and lower sludge production have made them more favorable technique (Dawkar et al., 2010). Biological degradation can be performed under both aerobic and anaerobic conditions and aerobic degradation is more efficient than anaerobic degradation (Shah 2014 \& Ramadan et al., 2014; Chengalroyen et al., 2013; Saratale et al., 2011). The treated industrial wastewater can be used for irrigation purpose, particularly for growing crops in degraded soils (Iqbal et al., 2010). Furthermore, screening efficient fungal and bacterial strains that can cleave azo bonds of complex azo dye structures could be useful for the effective treatment of textile effluents.

Though most of the research work on dye decolonization have been carried out using individual fungal and bacterial cultures but the work pertained to fungal-bacterial synergism for biodegradation of DR81 is missing. In this regards, cell immobilization technique is studied for its potential to improve bioremediation and fermentation processes. There are two immobilization methods that are widely used which are is entrapment and adsorption but the adsorption method is more simple and better physiological conditions (Kattimani et al., 2009). It was found that bacterial cultures able to utilize dyes as carbon or nitrogen sources, but mostly microorganism cannot utilize dyes as a sole carbon or nitrogen source so it needs organic carbon and nitrogen sources for dye degradation (Palanivelan et al., 2014).

In this study, microbial decolorization of DR81 has investigated aerobically with pure and mixed culture and because of DR81 is an azo dye extensively used in textile dyeing; this dye has been selected for the present study. The purpose of this study was examined for their ability to decolorize the recalcitrant DR81 in industry wastewaters, and how to enhance the activity of decolorization with immobilizing cells in different solid supports as activated charcoal, marine sand, ash, and kaolin. Bacillus pumilus as a bacterium isolate and Aspergillus clavatus as a fungal isolate were used as a specific strain that could be applied to a pure or mixed culture for the 
decolorization of synthetic wastewater that contained DR 81.

\section{Materials and Methods}

\section{Azo dye and chemical reagents}

The direct azo dye, Direct Red 81 (DR81) was used as a target dye for the synthetic wastewater and purchased from SigmaAldrich $^{\circledR}$. The initial concentration of the azo dye was fixed at approximately $100 \mathrm{mg} / \mathrm{L}$. DR81 $(\lambda \max =508 \mathrm{~nm})$, has a complicated molecular formula (C29H19N5Na2O8S2) (Heravi et al., 2015; Hossein and Behzad 2012). The stock solution of DR81 (5000 $\mathrm{mg} / \mathrm{L}$ ) was prepared in distilled water and further diluted to various low concentration solutions. The initial concentration of the azo dye was fixed at approximately $100 \mathrm{mg} / \mathrm{L}$. All chemicals and medium components were obtained from Hi Media Laboratories Pvt. Ltd., Mumbai, India. All the other chemicals used in the present study were of an analytical grade and highest purity available.

\section{Samples collection}

A total of 44 effluent samples were collected from in and around the Textile Industrial Zone (EL-Salam and Micado and other factories), in the form of untreated liquid effluent, 6th of October City, Cairo, Egypt as well as $10^{\text {th }}$ of Ramadan, El Sharkeya, Egypt. The collected effluent was transported to the laboratory in sterile glass-screw cap tubes. The $\mathrm{pH}$ of the filtered effluent was maintained at 7.0 and stored at $4{ }^{\circ} \mathrm{C}$ temperature until processing to prevent contamination by non- indigenous microbes; however, samples commonly used within $24 \mathrm{~h}$ of sample collection.

\section{Screening of microbial isolates}

Ten $\mathrm{ml}$ of each textile wastewater sample was inoculated into $250 \mathrm{ml}$ volumetric conical flask containing $100 \mathrm{ml}$ of sterile Mineral Salt Medium (MSM) as a source of carbon and nitrogen (Ramdan et al., 2014). MSM had a composition of $(\mathrm{g} / \mathrm{L}) \mathrm{KH}_{2} \mathrm{PO} 4$, (1); $\mathrm{K}_{2} \mathrm{HPO} 4$, (1); $\mathrm{MgSO} 4,(0.5) ; \mathrm{CaCl}_{2},(0.1) ; \mathrm{NaCl},(1)$; $\mathrm{NH}_{4} \mathrm{NO} 3$, (1) and DR81, (0.1). The mixture was incubated at $30^{\circ} \mathrm{C}$ for 21 days under static condition before being transferred to fresh medium. After incubation, $2 \mathrm{ml}$ of cell suspensions were plated onto MSM with 2.5 $\%(\mathrm{w} / \mathrm{v})$ agar-agar medium and incubated at $30{ }^{\circ} \mathrm{C}$ for $48 \mathrm{~h}$. Microbial colonies that appeared on the agar medium were resuspended into the flask containing freshly prepared MSM broth spiked with the DR81. A total of 25 bacterial isolates and 18 fungal isolates were recovered from effluent samples and further streaked three times to get purified isolates. The bacterial and fungal isolates that showed the highest decolonization of the dye in a liquid medium in $120 \mathrm{~h}$ were selected. Out of 43 isolates, two potential isolates (one bacterium and one fungus) were selected and examined again for their potential to decolorize the dye in wastewaters. The purified cultures were preserved at $-80{ }^{\circ} \mathrm{C}$ in $15 \%(\mathrm{v} / \mathrm{v})$ glycerol for subsequent studies.

\section{Identification of degrading organisms}

\section{Bacterial identification of bacterial isolates}

After purification by successive single colony isolation on the agar plate, the bacterial isolate that showed the highest decolorization was selected and identified by the conventional microbiological methods. In this regard, the traditional method was obtained such as (i) Gram stain technique and (ii) Biochemical tests such as catalase and oxidase test, and commercially available multi test identification system: analytical profile index (API). $\quad \mathrm{API}^{\circledR}$ identification products are identification test kits for Gram positive and Gram negative bacteria and yeast. API $^{\circledR}$ strips identifications based on extensive databases 
and are standardized, easy-to-use test systems and it gives accurate identification. API ${ }^{\circledR}$ strips contain up to 20 miniatures, quick biochemical tests, and all are safe and easy to perform. Test strips were used as the instructions provided.

\section{Fungal identification}

PCR and sequencing technique was performed fungal isolate identification by Clinilab, 160 St., El-Etihad Square Riham Tower, ElMaadi, Cairo, Egypt.

\section{DNA extraction}

Fungal mycelia were scraped directly from the surface of an agar culture. The final mycelial mat was weighed before placing it into a ceramic mortar. Liquid nitrogen was added to the tissue for grinding. After sufficient grinding extraction buffer $[100 \mathrm{mM}$ Tris- $\mathrm{HCl}$ (pH 8.0), $20 \mathrm{mM} \mathrm{Na} 2$ EDTA, $0.5 \mathrm{M} \mathrm{NaCl}, 1 \%$ sodium dodecyl sulfate and proteinase $\mathrm{K}$ (3 $\mathrm{mg} / \mathrm{mL}$ proteinase $\mathrm{K}$ (added fresh)] was added to the mortar so that the homogenate became ready. A mixture of buffer saturated phenol/chloroform/isoamyl alcohol was added at a ratio of $0.5 \mathrm{ml}$ per gram of tissue.

The mixture was ground vigorously for $\sim 30$ sec with a vortex to form a thick paste. Two $\mathrm{ml}$ of extraction buffer and $1 \mathrm{ml}$ of buffered phenol/ $/ \mathrm{CHCl}_{3} /$ isoamyl alcohol per $0.5 \mathrm{~g}$ of starting tissue were then added, and the solution was mixed thoroughly. The mixture was transferred into several microfuge tubes using a micropipette. The microfuge tubes were capped and centrifuged at $14,000 \mathrm{rpm}$ for $5 \mathrm{~min}$ at room temperature. The aqueous phase was transferred to a new tube and was mixed with 0.1 volume of $3 \mathrm{M}$ sodium acetate $(\mathrm{pH}=5)$ and 2.5 volume absolute ethanol. The solution was gently mixed by inversion until the white thread-like strands of DNA forming a visible mass. Samples were incubated at $-20^{0} \mathrm{C}$ for
$30 \mathrm{~min}$ and centrifuged for $15 \mathrm{~min}$ at 14,000 rpm to recover the precipitate. The supernatant was decanted and $500 \mu \mathrm{l}$ of room temperature $70 \%$ ethanol was added to the DNA pellet. The tube was gently inverted several times to wash the DNA pellet. The sample was centrifuged at 14,000 rpm for one min at room temperature. The ethanol was carefully aspirated using micropipette tip. The tube was inverted on clean tissue paper and the pellet was air-dried for $15 \mathrm{~min}$. Also, 50-100 $\mu$ of TE buffer $\left(10 \mathrm{mM}\right.$ Tris- $\mathrm{HCl}$, one $\mathrm{mM} \mathrm{Na} \mathrm{Na}_{2}$ EDTA, pH 8.0) was added to the tube and DNA was dissolved by incubating at $65^{\circ} \mathrm{C}$ for an hour and then stored at $(2-8){ }^{\circ} \mathrm{C}$ for subsequently used.

For determination of DNA quality, quantity and integrity; samples were characterized using a UV spectrophotometer (Model: UV $1800240 \mathrm{~V})$ by measuring absorbance at $260 / 280 \mathrm{~nm}$ followed by visualization in gel electrophoresis stained by ethidium bromide. Ratios between 1.8 and 2.3 were considered satisfactory.

Agarose gel electrophoresis $(0.8 \%)$ for genomic DNA integrity determination

Agarose (0.8 grams) (Catalog number: 901236-6, Sigma, USA) were added to $100 \mathrm{ml} 1 \mathrm{X}$ TAE buffer (Tris-Acetate-EDTA) prepared from 50X TAE buffer (Catalog number: B52, Thermo Scientific, USA) where it was diluted 50 times by double distilled water. This solution was heated in microwave oven until agarose was dissolved. Then the solution was cooled to $50^{\circ} \mathrm{C}$, and $2.5 \mu \mathrm{l}(10 \mathrm{mg} / \mathrm{ml})$ ethidium bromide was added to the agarose solution, mixed well and then poured into the appropriate tray. After the agarose solidified, it was transferred to the horizontal electrophoresis submarine (Biometra, Compact multi_wide). The submarine was filled with 1X TAE buffer till the buffer totally covered the agarose gel, $5 \mu \mathrm{l}$ of each 
sample was mixed with $1 \mu \mathrm{l}(6 \mathrm{X})$ loading dye (Catalog number: R0611, Thermo Scientific, USA) and loaded in the gel wells, $5 \mu \mathrm{l}$ of $1 \mathrm{~kb}$ DNA ladder (Catalog number: 10787-018, Invitrogen, USA). Also, five $\mu 1$ of uncut lambda $(\lambda)$ DNA ladder $(35 \mathrm{ng} / \mu \mathrm{l})$ (Catalog number: SD0011, Invitrogen, USA) was loaded to the agarose gel. The submarine was closed with its lid and connected to power supply (Biometra, Standard Power Pack P25 T); a voltage of about 120 volts was applied for about $30 \mathrm{~min}$. After the run was completed, the gel was visualized using gel documentation system (Biometra GmbH BDA Box 2).

Amplification of Internal Transcribed Spacer (ITS) regions of fungal ribosomal DNA (rDNA)

\section{Polymerase Chain Reaction (PCR)}

The primers used for universal fungal DNA amplification from all isolates were for intervening ITS1, and ITS2 rRNA gene regions. The size of the product generated varies according to the organism tested. Primers used for direct sequencing were ITS 1; 5'-TCC GTA GGT GAA CCT GCG G-3' (position corresponding to small subunit 17691787), and ITS4; 5'-TCC TCC GCT TAT TGA TAT GC-3' (position corresponding to large subunit 41-60). All primers were synthesized by Invitrogen by Thermo Fisher Scientific Co.

PCR was conducted using GoTaq Flexi DNA Polymerase, 100u (units), Catalog number: M8291, Promega Corporation Madison, WI 53711-5399 USA. $25 \mu \mathrm{l}$ reaction mixtures were prepared to consist of GoTaq ${ }^{\circledR}$ Flexi DNA Polymerase, 5X Colorless GoTaq ${ }^{\circledR}$ Flexi Buffers, Magnesium Chloride Solution and specific primers which were ordered from Invitrogen Company, 3175 Staley Road Grand Island, NY 14072, USA.

\section{DNA sequencing}

All PCR-amplified products were sequenced at Clinilab by automated dye termination sequencing. Each PCR-amplified product was purified with High Pure PCR Product Purification Kit (Catalog Number: 11732668 001, Roche Applied Sciences, Germany) and sequenced using a 16-capillary 3100 Genetic Analyzer (Applied Biosystems). The ABI Prism BigDye Terminator Cycle Sequencing Ready Reaction Kit Version 3 (Applied Biosystems) was used with protocols supplied by the manufacturer. PCR-amplified products from cultures were sequenced in a forward and reverse direction using ITSl primer and the ITS4 primer respectively. Sequences were visualized and edited using SEQSCAPE Version 1.1 (Applied Biosystems).

\section{Data Analysis}

GenBank search Sequence was performed using the BLAST standard nucleotidenucleotide primary local alignment search tool [National Center for Biotechnology Information (NCBI), Library of Medicine, Bethesda, MD, USA (http://www.ncbi.nlm.nih.gov/BLAST/)].

\section{Maintenance of stock cultures}

The bacterial isolate was maintained on slants of agar-agar (2\%) supplemented with $50 \mathrm{mg} / \mathrm{L}$ of DR81, while the fungal isolate was maintained on Czapek Dox agar slants. Isolates were incubated at $28^{\circ} \mathrm{C}$ for five days and then stored at $4^{\circ} \mathrm{C}$ and sub-cultured every two months.

\section{Decolorization studies}

\section{Plate assay}

Plate assay was performed for the detection of decolorizing activity of the recovered isolates. 
The nutrient agar was autoclaved at $121^{\circ} \mathrm{C}$ for 15 min. then DR81 was added after agar became warm. Isolates were plated on nutrient agar for bacterial isolate and sabouraud agar for fungal isolate (Vinodhkumar et al., 2013), or inoculated into agar well plates containing DR81 (100 mg /L). The plates were wrapped with parafilm and were incubated at $37^{\circ} \mathrm{C}$ for 7 days. The plates were observed for clearance of the dye surrounding the colonies (Vinodhkumar et al., 2013) or surrounding the wells.

Decolorization assay of direct red 81 in liquid medium

Decolorization assays of the recovered isolates were done in MSM amended with $100 \mathrm{mg} / \mathrm{L}$ of the tested dye. The decolorization test was then performed by adding $5 \%(\mathrm{v} / \mathrm{v})$ of the inoculum into Erlenmeyer flasks containing $50 \mathrm{ml}$ of the MSM and $\mathrm{pH}$ adjusted to be 6.5 with $0.1 \mathrm{M}$ phosphate buffer. After incubation $\left(30^{\circ} \mathrm{C}\right.$ under aerobic and agitation condition where incubator shaker worked at $150 \mathrm{rpm}$ [Model Innova ${ }^{\circledR}$ 42R Inc/Ref Shaker, New Brunswick, US]) broth cultures were withdrawn daily at specified time interval for successive five days. Moreover, they were centrifuged at $10,000 \mathrm{rpm}$ for $15 \mathrm{~min}$. at room temperature for removal of biomass.

Then the supernatants were collected to obtain their optical density (OD) to be measured at $508 \mathrm{~nm}$ under visible light in the spectrophotometer (Model: UV - 1800 240V).

The optical density of the control (uninoculated) flasks was also measured. Finally, the rate of decolorization was calculated as the percent of decolorization (\%)

Decolorization activity $(\%)=(\mathrm{Ai}-\mathrm{At}) / \mathrm{Ai} \mathrm{X}$ 100

Where $\mathrm{Ai}=$ initial absorbance
At $=$ observed absorbance (the concentration at cultivation time $(0,1,2,3,4$ and 5 days $)$

Each test was performed triplicate and mean values expressed as a result.

\section{Decolorization of dye in industrial wastewaters}

This experiment was carried out to reveal the effect of recovered isolates on industrial wastewaters. Cell suspension $(2 \mathrm{ml})$ with a density of $10^{6}$ was used to inoculate $100 \mathrm{ml}$ flask containing $50 \mathrm{ml}$ industrial wastewater with $100 \mathrm{mg} / \mathrm{L}$ of DR81, using abiotic control with DR81. The fungal mass was determined along with decolorization reaction at the same time intervals of samples withdrawn to determine fungal survival.

\section{High Performance Liquid Chromatography (HPLC)}

This method was carried out according to (Sahasrabudhe et al., 2014) with some alteration. The removal of Direct Red 81 azo dye and a generation of decolorization products was monitored using an HPLC system equipped with an ODS C18 column (Shimadzu SPD 20A) with HPLC grade methanol $70 \%+30 \%$ deionized water as mobile phase at the flow rate of $1.0 \mathrm{~mL} / \mathrm{min}$ for $10 \mathrm{~min}$ at $508 \mathrm{~nm}$. A portion of the sample (10 microliters) was manually injected into the injector port, and then the metabolites were analyzed using a dual absorbance UV detector.

\section{Effect of carbon and nitrogen sources on the extent of degradation}

Overnight incubation for microorganisms, the growing colonies was suspended in standard saline solution to obtain the optical density of $10^{6}-10^{7} \mathrm{CFU} / \mathrm{ml}$ (0.6 at $610 \mathrm{~nm}$ wavelength). A portion of two milliliters of cell suspension 
were used to inoculate $100 \mathrm{ml}$ flask containing $50 \mathrm{ml} \mathrm{MSM}$ with $1 \%$ of each yeast extract or glucose. The used dye concentration was 100 $\mathrm{mg} / \mathrm{L}$. Flasks incubated for five days at $37^{\circ} \mathrm{C}$ at $150 \mathrm{rpm}$ (Sahasrabudhe et al., 2014; Palani Velan et al., 2012). The percentage of azo dye decolorization was determined for each flask daily as previously mentioned.

\section{Microbial degradation of azo dyes by mixed cultures}

A liquid medium (MSM) amended with $100 \mathrm{mg} / \mathrm{L}$ of DR81 was used for mixed culture assay. Mixed culture of bacterial and fungal isolates was inoculated $\left(10^{7} \mathrm{CFU} / \mathrm{ml}\right)$ into the medium. Flasks were incubated at $37^{\circ} \mathrm{C}$ under aerobic and agitation condition at 150 RPM. Samples were detected by UV-Vis Spectrophotometer at $508 \mathrm{~nm}$ wavelength for determination of DR81 percent of decolorization at different time intervals. Control was performed with the same procedure but without inoculation.

\section{Microbial Degradation of DR81 by Immobilized Cells}

Immobilization experiment was performed to increase the potential capacity of the cells for decolorization. Different solid supports (20 $\mathrm{g} / \mathrm{L}$ ) of ash, marine sand, activated charcoal (AC) or Kaolin of Aldrich were added to a liquid MSM. Recovered isolates were immobilized in solid supports according to the procedure given by (Pokharia and Ahluwalia 2016; Kattimani et al., 2009) with some modification. All solid supports were sieved and sterilized at $121^{\circ} \mathrm{C}$ for $15 \mathrm{~min}$. One gram of solid support was submerged in $250 \mathrm{ml}$ Erlenmeyer flask containing $50 \mathrm{ml}$ MSM containing a proper concentration of tested isolates, then after 10 days of incubation under agitation condition $(150 \mathrm{rpm})$, the flasks supplemented with $100 \mathrm{mg} / \mathrm{L}$ of DR81 to determine the immobilization effect. Samples were detected at different time intervals by UV-Vis Spectrophotometer at $508 \mathrm{~nm}$ wavelength for determination of DR81 percent of degradation. All results were compared with control (uninoculated) which had zero percent of decolorization.

\section{Decolorization of dye in industrial wastewaters}

This experiment was carried out to reveal the effect of recovered isolates on industrial wastewaters. Cell suspension $(2 \mathrm{ml})$ with density of $10^{6}$ was used to inoculate $100 \mathrm{ml}$ flask containing $50 \mathrm{ml}$ industrial wastewater with $100 \mathrm{mg} / \mathrm{L}$ of DR81, using abiotic control with DR81. The fungal mass was determined along with decolorization reaction at the same time intervals of samples withdrawn to determine fungal survival.

\section{Statistical analysis}

Values of data were expressed as means of triplicates $\pm \mathrm{SD}$; statistics were analyzed by one way ANOVA followed by Tukey-Kramer multiple comparisons test; *: Reading were considered significant when $\mathrm{P}<0.05$.

\section{Results and Discussion}

\section{Isolation and identification of decolorizing isolates}

A total of 43 microbial isolates (25 bacterial isolates and 18 fungal isolates) were recovered as mentioned before. These isolates were then screened to figure out potential decolorizer of DR81 in a medium having $10 \%$ of the respective dye. Through the screening process, two isolates (one bacterial isolate and one fungal isolate) were selected as potential dye decolorizer and preserved for further study. Bacterial isolate was identified as Bacillus pumilus, and the fungal isolate was identified as Aspergillus clavatus. The bacterial isolate 
with the strongest decolorizing ability was identified by the conventional microbiological methods to the genus level and by commercially available multitest identification system: analytical profile index (API) (Figure 1). Test strips were used as the instructions provided. Fungal isolate identification was performed by Identification Unit of Fungi, Regional Center of Mycology and Biotechnology Azhar University, Cairo, Egypt. A fungal isolate Aspergillus clavatus was re-identified by PCR and sequencing. The gene sequence of Aspergillus clavatus has been deposited in GenBank with the accession number HQ026749.1 as shown in figure 2.

\section{Decolorizing assay}

\section{Detection of decolorization of DR81 by plate assay}

Decolorizing activity of degradable isolates was detected by plate assay. Clearing zone was formed surrounding the growing cultures on nutrient agar or Sabouraud agar plates containing $100 \mathrm{mg} / \mathrm{L}$ DR81 within 7 days. Isolates decolorization ability was shown in figure 3 . The diameter of decolorization zone was calculated after 7 days of incubation, Bacillus pumilus and Aspergillus clavatus showed the highest decolorization activity on DR81 compared to the other recovered isolates.

\section{Spectrophotometer analysis}

DR81 solution was analyzed by UV-Vis Spectrophotometer. Figure 4A describes that $100 \mathrm{mg} / \mathrm{L}$ of DR81 solution absorbed light maximally at $508 \mathrm{~nm}$. Decolorization results with Bacillus pumilus after 5 days showed that the main peak at $508 \mathrm{~nm}$ decreased approximately (Figure 4B) while the peak was completely disappeared with Aspergillus clavatus after 2 days (Figure 4C). In this regard, the main peak at $281 \mathrm{~nm}$ was decreased after 5 days with bacteria while the peak was shifted to $335 \mathrm{~nm}$ with Aspergillus clavatus. The marked decrease of the peak at $508 \mathrm{~nm}$ by fungi indicates almost complete decolorization of DR81. Decolorization percentage of DR81by both Bacillus pumilus and Aspergillus clavatus was shown in Table 1 .

\section{High Performance Liquid Chromatography analysis (HPLC)}

After 5 days of aerobic treatment process, HPLC analysis for biodegradation products was carried out. HPLC analysis of DR81 as a control showed a peak at the retention time of $1.588 \mathrm{~min}$. (Figure 5A), and there was no new peak was observed with Bacillus pumilus indicating that decolorization was due to its degradation into unidentified intermediates, while Aspergillus clavatus showed two metabolites peaks at the retention times of 2.036 and $4.257 \mathrm{~min}$. (Figure 5B). All samples showed the appearance of dye peak in the metabolites along with appearance of new peaks with different retention times which supported dye biotransformation to different metabolites.

\section{Effect of carbon and nitrogen sources on the extent of biodegradation}

In this study, $1 \%$ of each glucose and yeast extract was used as a carbon and nitrogen source, respectively. Figure 6 shows the effect of different nitrogen and carbon sources on decolorization of DR81 by Bacillus pumilus and Aspergillus clavatus. After two days of incubation, the percentage of DR81 decolorization for Bacillus pumilus and Aspergillus clavatus without any supplement was $8 \%$ and $73 \%$, respectively. While the percentage of DR81 decolorization for Bacillus pumilus, when supplemented with yeast extract was $91 \%$ and $98 \%$ for Aspergillus clavatus. The decolorization 
percent of DR81 with glucose was found to be $20 \%$ for Bacillus pumilus and $98 \%$ for Aspergillus clavatus (Table 2). Aspergillus clavatus obtained the high extent of decolorization after 2 days of incubation. Yeast extract and glucose had the same effect with Aspergillus clavatus while yeast extract was more efficient than glucose with Bacillus pumilus.

\section{Degradation of DR81 by mixed culture}

This experiment was performed to see the effect of mixed culture on decolorization of DR81. Bacillus pumilus and Aspergillus clavatus used together as a mixed culture. Percent of dye degradation increased from $17.48 \%$ to $87.69 \%$ by Bacillus pumilus and Aspergillus clavatus mixed culture with regard to Bacillus pumilus degradation as shown in Table 3.

\section{Effect of immobilized cells}

The efficiency of immobilized microbial cells to decolorize the DR81 was investigated at agitated conditions. Immobilized bacterial cells on ash were able to degrade about $56 \%$ of initial dye concentration while immobilized fungal cells were degrading about $65 \%$. The percentage of DR81 decolorization when using marine sand as solid support with Bacillus pumilus was $31 \%$ while it was $52 \%$ with Aspergillus clavatus. Furthermore, immobilized Bacillus pumilus cells on activated charcoal were degrading $52 \%$ of the dye while immobilized Aspergillus clavatus cells were degrading $74 \%$ of initial dye concentration. And when using kaolin as a solid support, bacterial degradation was $71 \%$ while fungal degradation was $70 \%$. The results obtained in this method indicate that the percentages of DR81 decolorization for free bacterial and fungal cells were $17 \%$ and $95 \%$, respectively of initial dye concentration within 5 days of incubation. Bacillus pumilus immobilized cells had the best decolorization effect on kaolin (71\%) (Table 4), while Aspergillus clavatus immobilized cells had the best decolorization effect on activated charcoal $(74 \%)$ of the initial dye concentration at the same time interval. Nevertheless, the unexpectedly result was obtained with Aspergillus clavatus free cells that had the highest extent of DR81 decolorization (94.93\%) compared to their immobilized cells on different solid supports, as shown in Table 5 .

\section{DR81 decolorization in industrial wastewaters}

This experiment was carried out to determine the capacity of the microbial degraders to function in industrial wastewaters. Low inoculum density of Aspergillus clavatus showed more significant DR81 decolorization in sterile condition than in non-sterile one. High inoculum density had a better effect than low concentration. These results illustrated after five days of incubation as shown in figure 7 .

\section{Survival of Aspergillus clavatus in industrial wastewater}

This experiment determined the survival rate of the dry weight of Aspergillus clavatus as shown in figure 8 . The present data showed that Aspergillus clavatus could not survive in industrial wastewater for a long time. Discharge of textile azo dyes to the environment is an issue of health concern while the use of the biological system has proved to be the best option for remediation. The effluents of industrial dyes are the major sources of water pollution, threatening the existence of aquatic biodiversity; alternate eco-friendly approaches are needed to remediate the dye-contaminated wastewaters discharged from a range of textile industries (Aruna et al., 2015). 
Table.1 Decolorization percentage of DR81 (100 mg/L)

\begin{tabular}{|c|c|c|c|}
\hline Microbial isolates & $\begin{array}{c}\text { Absorbance at 508 } \\
\text { nm }\end{array}$ & $\begin{array}{c}\text { Percentage of dye } \\
\text { decolorization }\end{array}$ & $\begin{array}{c}\text { Percentage of dye } \\
\text { remaining }\end{array}$ \\
\hline Bacillus pumilus & $1.8 \pm 0.15$ & $17.479 \%$ & $82.52 \%$ \\
\hline Aspergillus clavatus & $* 0.69 \pm 0.72$ & $94.929 \%$ & $5.07 \%$ \\
\hline
\end{tabular}

Values are expressed as means of triplicates \pm SD; statistics was carried out by one way ANOVA followed by Tukey test; *: significantly different from control value at $\mathrm{P}<0.05$.

Table.2 Effect of glucose and yeast extract on decolorization percent of $100 \mathrm{mg} / \mathrm{L}$ DR81 by bacterial and fungal isolates after 2 days incubation

\begin{tabular}{|c|c|c|}
\hline \multirow[t]{2}{*}{ Supplements } & \multicolumn{2}{|c|}{$\begin{array}{c}\text { Extent of DR81 degradation by Bacillus pumilus } \\
\text { and Aspergillus clavatus }\end{array}$} \\
\hline & Bacillus pumilus & Aspergillus clavatus \\
\hline Supplement-free & $8 \%$ & $73 \%$ \\
\hline With Glucose & $20 \%$ & $98 \%$ \\
\hline With Yeast extract & $91 \%$ & $98 \%$ \\
\hline
\end{tabular}

Table.3 Decolorization \% of DR81 by Bacillus pumilus /Aspergillus clavatus mixed culture

\begin{tabular}{|l|c|c|c|}
\hline Microbial isolates & $\begin{array}{c}\text { Absorbance } \\
\text { at 508 }\end{array}$ & $\begin{array}{c}\text { Percentage of dye } \\
\text { decolorization }\end{array}$ & $\begin{array}{c}\text { Percentage of } \\
\text { dye remaining }\end{array}$ \\
\hline Bacillus pumilus & $1.8 \pm 0.15$ & $17.48 \%$ & $82.52 \%$ \\
\hline Aspergillus clavatus & $* 0.69 \pm 0.72$ & $94.93 \%$ & $5.07 \%$ \\
\hline $\begin{array}{l}\text { Bacillus pumilus } \text { with } \\
\text { Aspergillus clavatus }\end{array}$ & $* 0.7 \pm 0.7$ & $87.69 \%$ & $12.31 \%$ \\
\hline
\end{tabular}

Values are expressed as means of triplicates $\pm \mathrm{SD}$; statistics was carried out by one way ANOVA followed by Tukey test; *: significantly different from control value at $\mathrm{P}<0.05$.

Table.4 Decolorization \% of DR81 by free and immobilized cells of Bacillus pumilus

\begin{tabular}{|c|c|c|c|}
\hline $\begin{array}{c}\text { Free/ immobilized } \\
\text { cells }\end{array}$ & $\begin{array}{c}\text { Absorbance at } \\
\mathbf{5 0 8} \mathbf{~ n m}\end{array}$ & $\begin{array}{c}\text { Percentage of dye } \\
\text { decolorization }\end{array}$ & $\begin{array}{c}\text { Percentage of } \\
\text { dye remaining }\end{array}$ \\
\hline Free cells & $1.8 \pm 0.15$ & $17.48 \%$ & $82.52 \%$ \\
\hline $\begin{array}{c}\text { Immobilized cells } \\
\text { with ash }\end{array}$ & $* 1.3 \pm 0.48$ & $55.93 \%$ & $44.07 \%$ \\
\hline $\begin{array}{c}\text { Immobilized cells } \\
\text { with marine sand }\end{array}$ & $1.73 \pm 0.29$ & $32.05 \%$ & $67.95 \%$ \\
\hline $\begin{array}{c}\text { Immobilized cells } \\
\text { with activated } \\
\text { charcoal }\end{array}$ & $* 1.56 \pm 0.49$ & $51.58 \%$ & $48.42 \%$ \\
\hline $\begin{array}{c}\text { Immobilized cells } \\
\text { with kaoline }\end{array}$ & $* 1.58 \pm 0.63$ & $70.91 \%$ & $29.09 \%$ \\
\hline
\end{tabular}

Values are expressed as means of triplicates $\pm \mathrm{SD}$; statistics was carried out by one way ANOVA followed by Tukey test; *: significantly different from control value at $\mathrm{P}<0.05$. 
Table.5 Decolorization \% of DR81 by free and immobilized cells of Aspergillus clavatus

\begin{tabular}{|l|c|c|c|}
\hline $\begin{array}{l}\text { Free/ immobilized } \\
\text { cells }\end{array}$ & $\begin{array}{c}\text { Absorbance at } \\
\mathbf{5 0 8} \mathbf{~ n m}\end{array}$ & $\begin{array}{c}\text { Percentage of dye } \\
\text { decolorization }\end{array}$ & $\begin{array}{c}\text { Percentage of } \\
\text { dye remaining }\end{array}$ \\
\hline Free cells & $* .69 \pm 0.72$ & $94.93 \%$ & $5.07 \%$ \\
\hline $\begin{array}{l}\text { Immobilized cells } \\
\text { with ash }\end{array}$ & $1.18 \pm 0.54$ & $64.75 \%$ & $35.25 \%$ \\
\hline $\begin{array}{l}\text { Immobilized cells } \\
\text { with marine sand }\end{array}$ & $1.53 \pm 0.44$ & $51.69 \%$ & $48.31 \%$ \\
\hline $\begin{array}{l}\text { Immobilized cells } \\
\text { with activated } \\
\text { charcoal }\end{array}$ & $1.3 \pm 0.65$ & $73.76 \%$ & $26.24 \%$ \\
\hline $\begin{array}{l}\text { Immobilized cells } \\
\text { with kaoline }\end{array}$ & $1.3 \pm 0.66$ & $70.11 \%$ & $29.89 \%$ \\
\hline
\end{tabular}

Values are expressed as means of triplicates \pm SD; statistics was carried out by one way ANOVA followed by Tukey test; *: significantly different from control value at $\mathrm{P}<0.05$.

Fig.1 API 50 Ch: for identification of Bacillus pumilus

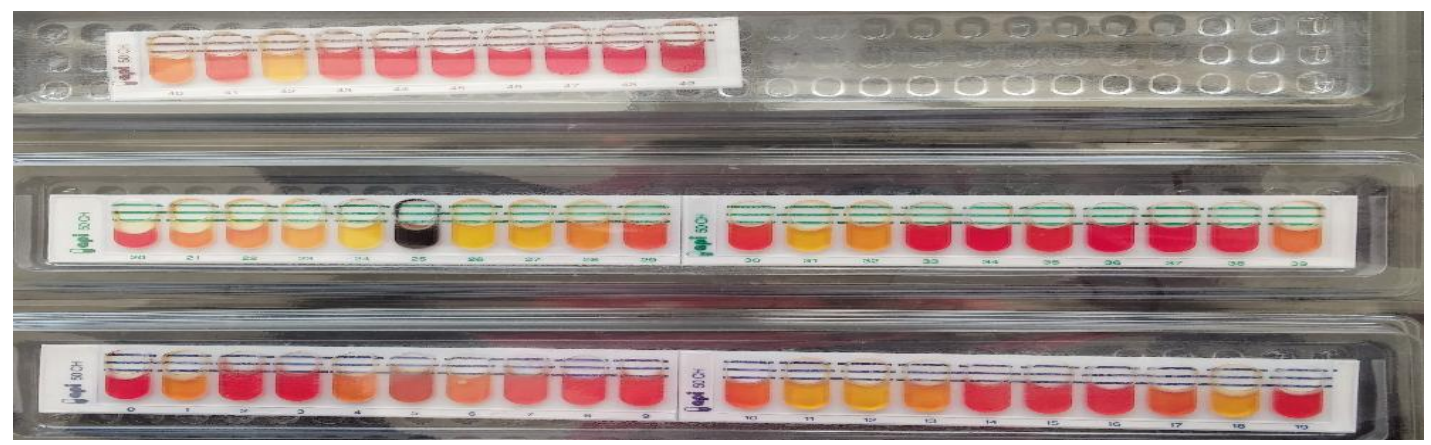

Fig.2 Phylogenic tree of Aspergillus clavatus strain. This tree was produced using BLAST pairwise alignments

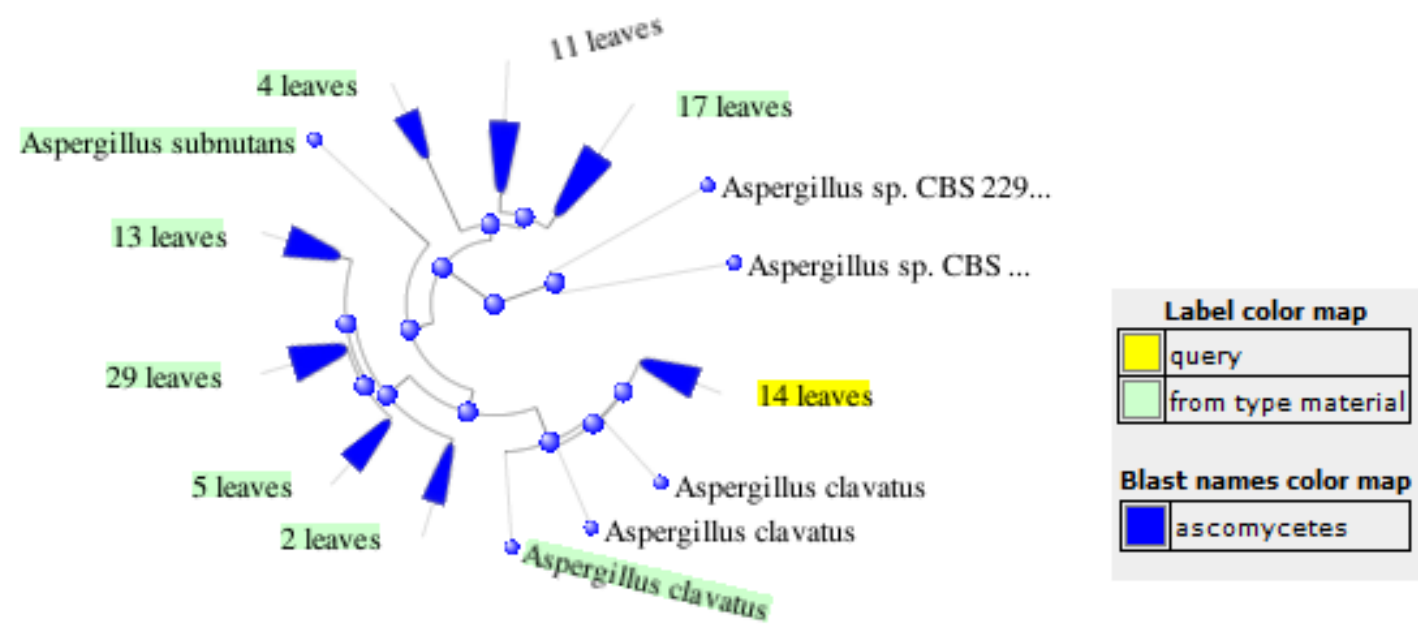


Fig.3 Decolorization activity of potent isolates by plate assay of DR81 (100 mg/L). (A) Bacillus pumilus and (B) Aspergillus clavatus

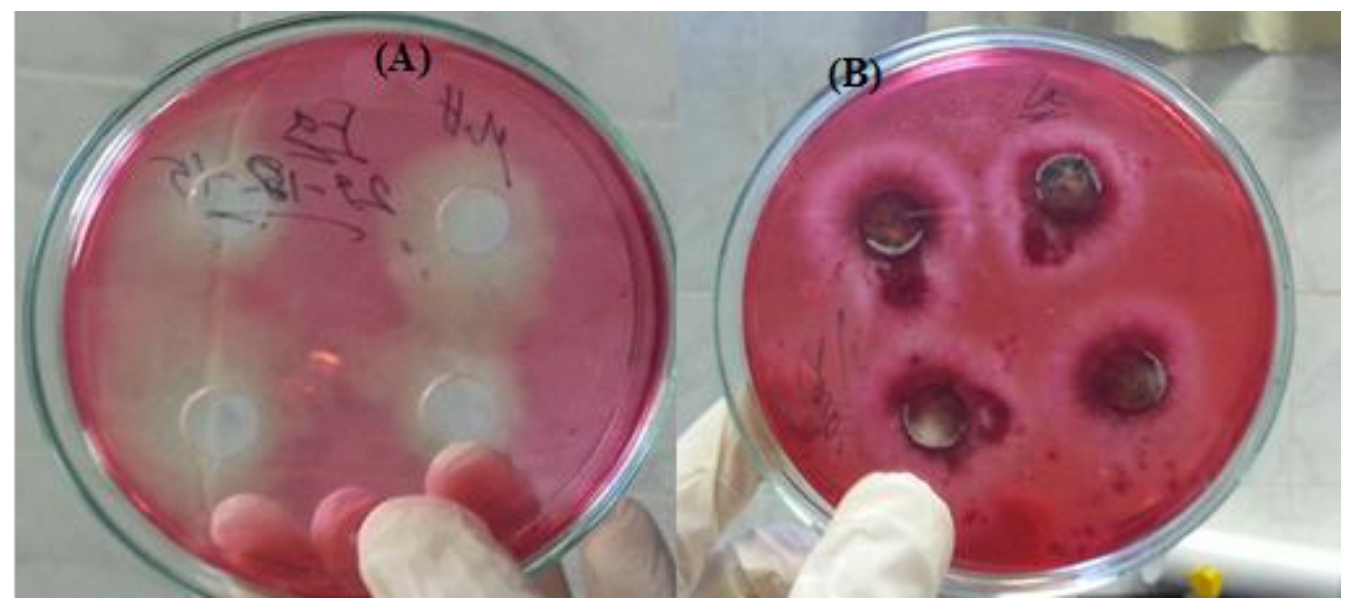

Fig.4 (A) UV-vis spectra (200-800 nm) of DR81 (100mg/L) in MSM, (B) UV-vis spectra of DR81 (100 mg/L) in MSM, before and after decolorization by Bacillus pumilus and (C) UV-vis spectra of DR81 (100 mg/L) in MSM, before and after decolorization by Aspergillus clavatus
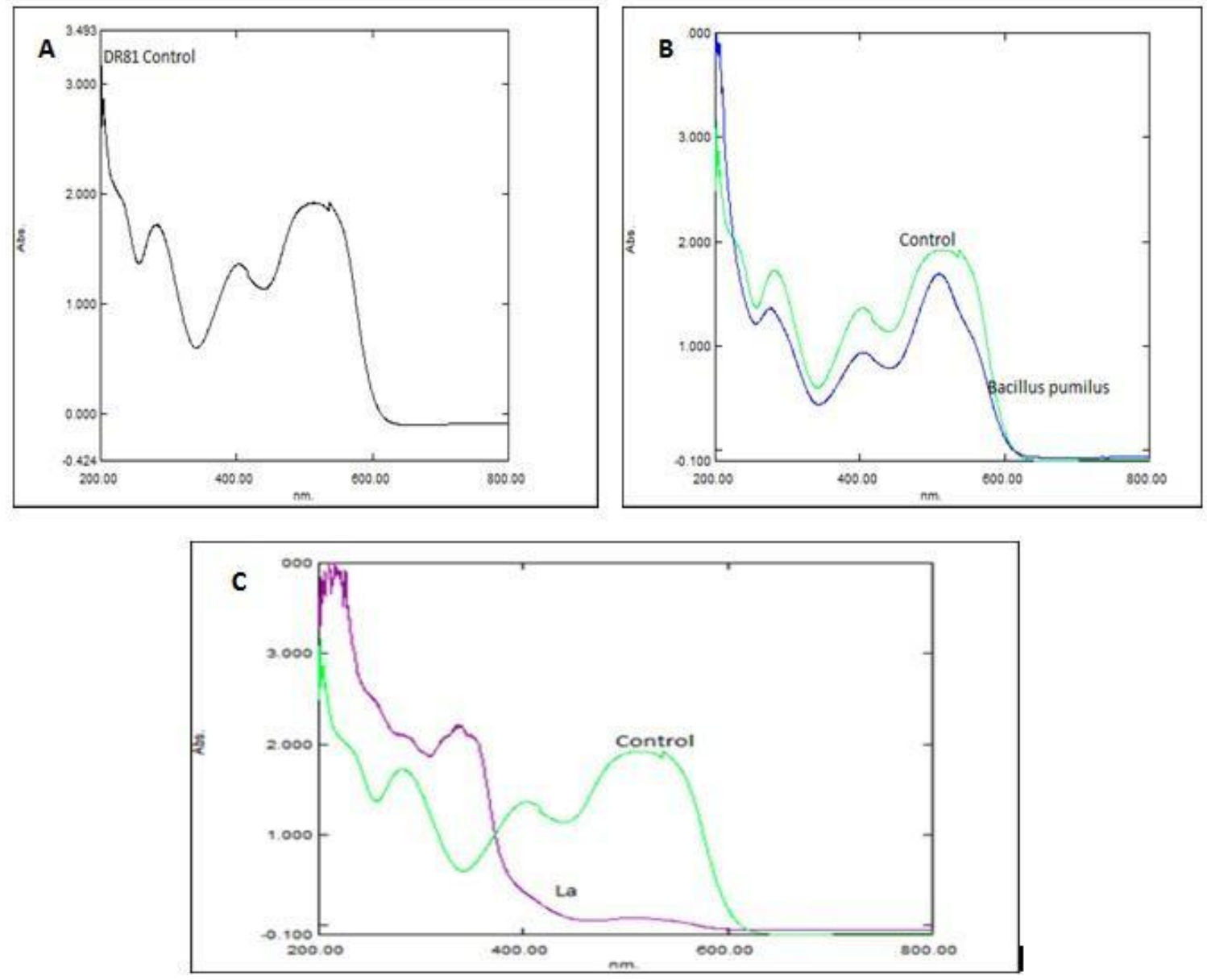
Fig.5 (A) HPLC profile of $100 \mathrm{mg} / \mathrm{L}$ DR81 and (B) HPLC profile of DR81 treated by Aspergillus clavatus, showing dye metabolites after decolorization
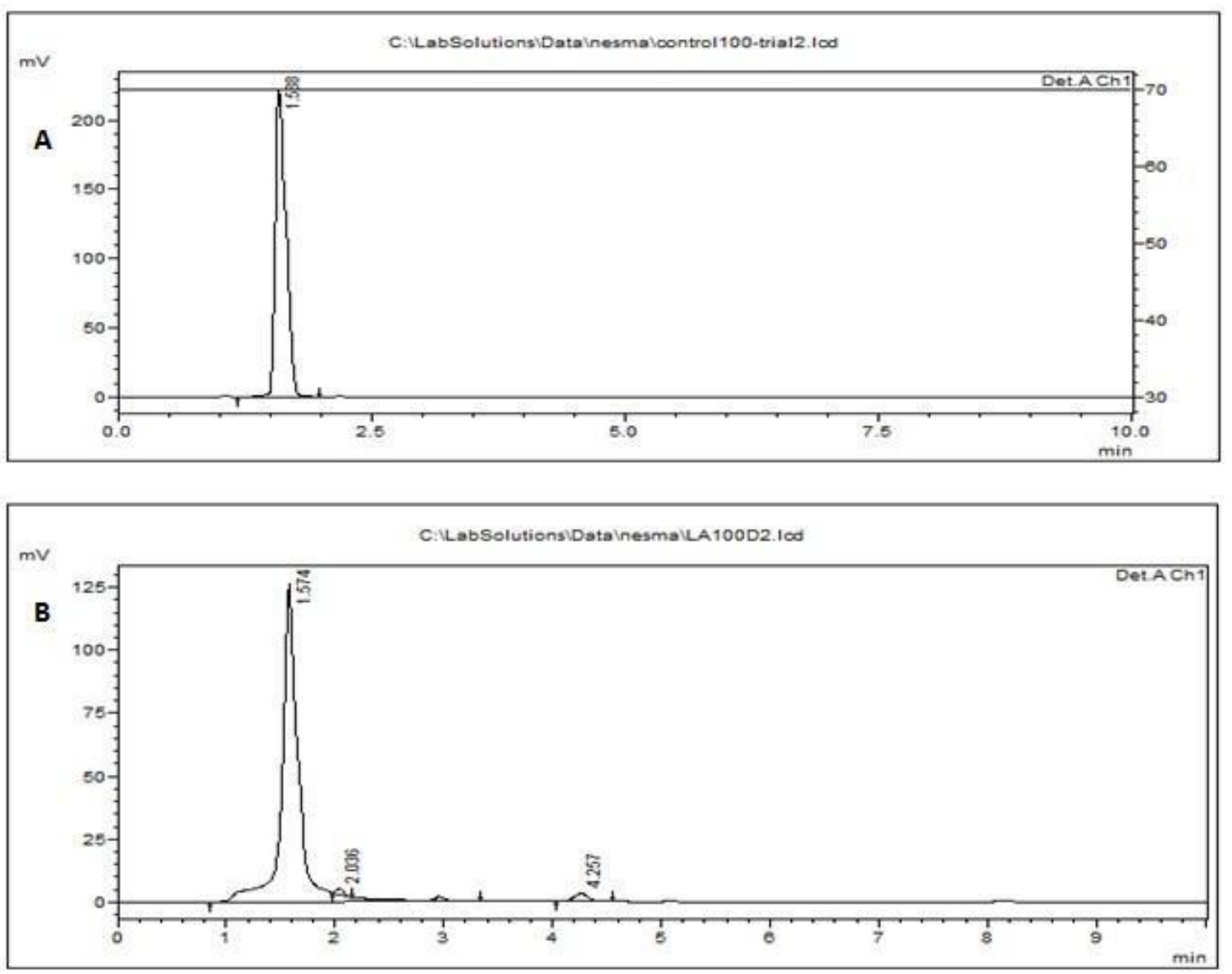

Fig. (6i) DR81 degradation after 2 days by Bacillus pumilus when supplemented with glucose or yeast extract

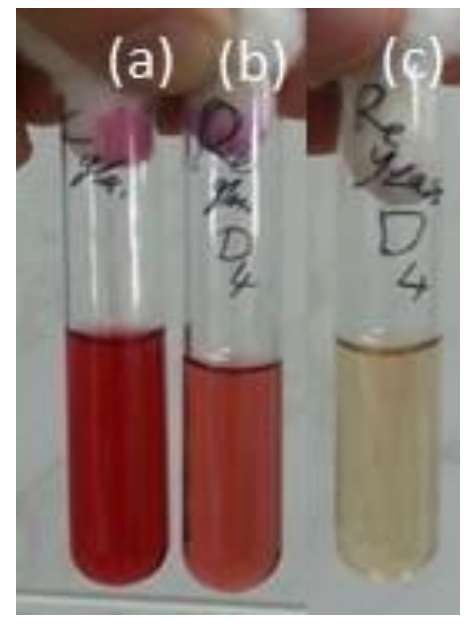

a) At zero time, b) supplemented with glucose, c) supplemented with yeast extract 
Fig. (6ii) DR81 degradation after 2 days by Aspergillus clavatus when supplemented with glucose or yeast extract

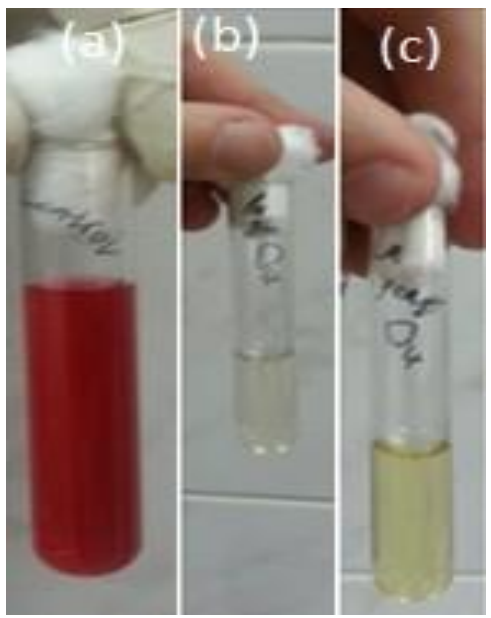

a) At zero time, b), supplemented with glucose c) supplemented with yeast extract

Fig.7 Decolorization percent of DR81 (100 mg/L) in industrial wastewater of low cell density of

(A) Bacillus pumilus, and (B) Aspergillus clavatus
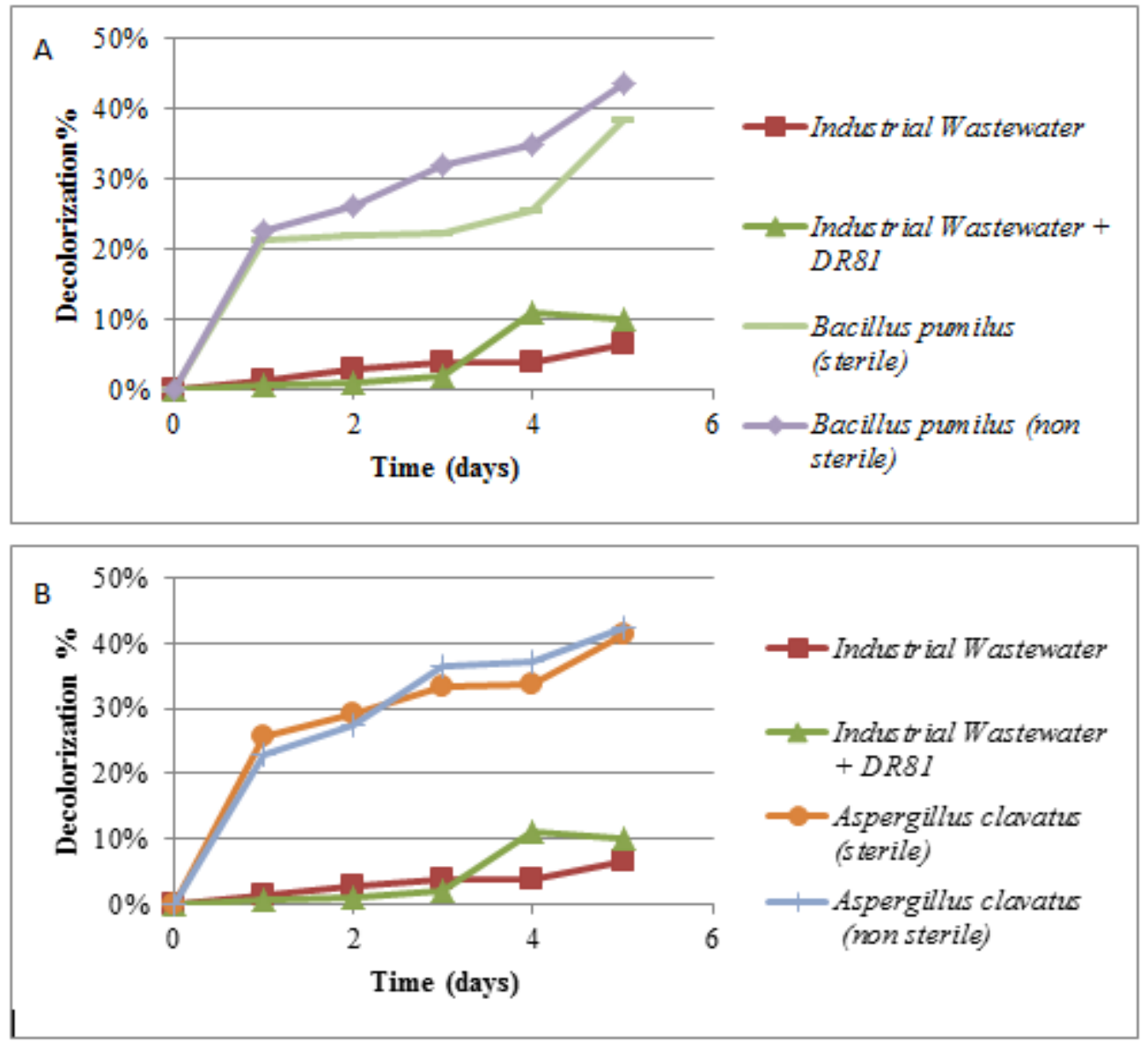
Fig.8 Fungal growth of Aspergillus clavatus during decolorization of DR81 in industrial wastewater

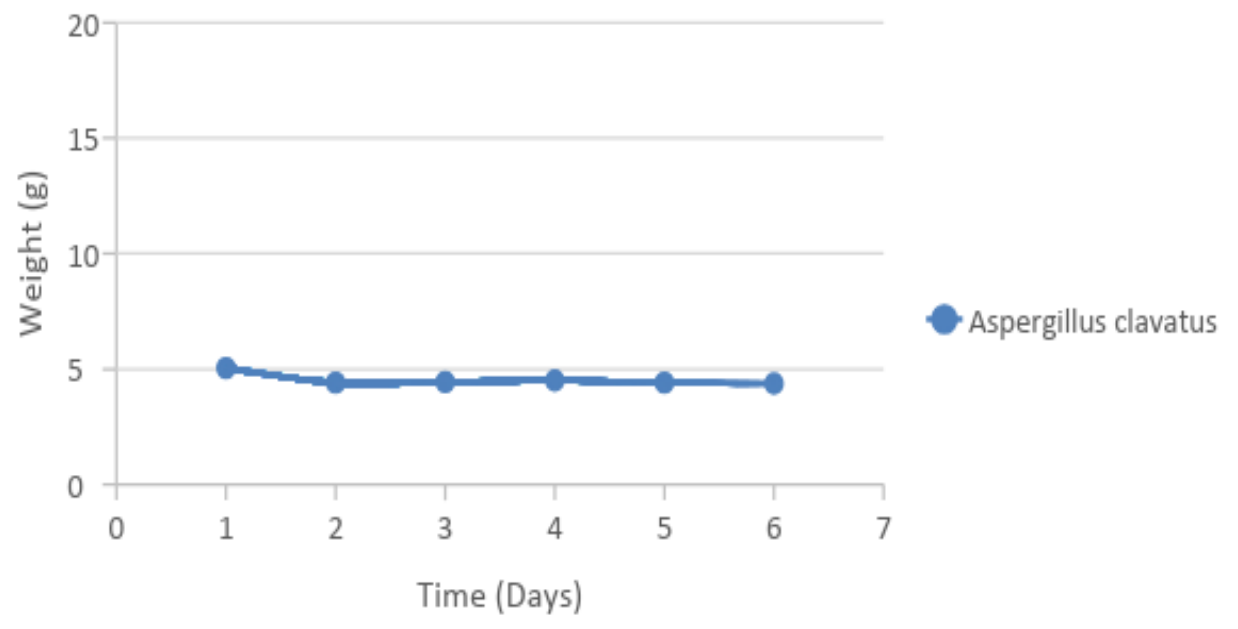

The objective of this study was evaluating the potential isolates that were screened out in solid/broth media for DR81 decolorization because of their consumption demand and extensively used azo dye in the textile industry (Lade et al., 2015; Kadam et al., 2011).

The bacterial culture showed the low extent of decolorization (17\%), while fungal culture showed higher decolorization (95\%). Many bacteria need the availability of a supplementary carbon source, and therefore they do not use azo dyes as a sole of carbon and energy source (Sahasrabudhe et al., 2014; Stolz, 2001), this is the reason for the low extent of bacterial decolorization On the other hands, fungi can produce the ligninmodifying enzymes to decolorize and/or mineralize azo dyes (Unyayar et al., 2005) and can also act by biosorption which defined as binding of solutes to the biomass. Also, the processes do not involve metabolic energy or transport (Mehta and Saini 2017; Bishnoi and Garima 2005; Tobin et al., 1994).

HPLC chromatographic analysis of biodegradation metabolites of DR81 by
Bacillus pumilus showed no new peak indicating that decolorization was due to its degradation into unidentified intermediates, while by Aspergillus clavatus it showed new metabolites peaks with different retention times (2.036 and $4.257 \mathrm{~min}$.).

As mentioned before, azo dyes are a lack in carbon source so, decolorization is difficult when to use it as a sole of carbon source (Palanivelan et al., 2014; Chang et al., 2004). Erum and Ahmed (2010) reported that excellent correlation between the decolorization speed and additional nutrient concentration reached up to $92.9 \%$ in a short time. Supplemental nutrients could change decolorization ability of azo dye. Therefore, in the present study effect of carbon and nitrogen sources on the extent of decolorization was demonstrated. Palanivelan et al., (2014); Jang et al., (2007) observed that addition of $1 \%$ yeast extract (as a nitrogen source) or glucose (as a carbon source) in the medium increased the color removal which also reported in the present study. After two days of incubation, decolorization of DR81 by Bacillus pumilus and Aspergillus clavatus without any supplement was $8 \%$ and $73 \%$, 
respectively. While it was $91 \%$ and $98 \%$ when yeast extract was supplemented as a nitrogen source for Bacillus pumilus and Aspergillus clavatus, respectively. Moreover, after two days of incubation, the percentage of DR81 decolorization with glucose was found to be $20 \%$ for Bacillus pumilus and that for Aspergillus clavatus was $98 \%$.

From the above data, it is observed that Aspergillus clavatus was more efficient in decolorizing DR81 than Bacillus pumilus. Yeast extract and glucose had the same effect with fungal isolate while yeast extract was more efficient in the decolorizing of DR81 than glucose with bacterial isolate. The use of organic nitrogen source yeast extract gave better decolorization and it counted as a fundamental supplement to regain $\mathrm{NADH}$ in the medium, that act as an electron donor for dye reduction by bacteria (Palanivelan et al., 2014; Hu 1994).

Most studies used the bacterial mixture or fungal mixture separately. Junnarkar et al., (2006) mentioned that decolorization of DR81 by a bacterial consortium was reached 8495\% while, Rathnan et al., (2013) mentioned that fungal dye decolorization was ranged from $85 \%$ to $100 \%$. In this study, two potential isolates were used as the bacterial/fungal mixture (Bacillus pumilus with Aspergillus clavatus).

Pure individual cultures of Bacillus pumilus and Aspergillus clavatus gave dye decolorization percent of $17.5 \%$ and $94.9 \%$, respectively while their mixed culture gave decolorization percent of $87.7 \%$. These results indicated that bacterial/fungal mixed culture had dye decolorization effect better than decolorization effect of pure bacterial culture.

Immobilized cells of Bacillus pumilus had much better decolorization effect on the DR81 compared to its free cells, and its best decolorization effect was with kaolin (71\%). This result indicates that the dye decolorization by immobilized bacterial cells is better than free cells. Chen et al., (2017); Kattimani et al., (2009); Rogalski et al., (1995) observed similar findings, concerning immobilization, who reported that it is a technique to enhance cells productivity and concentration.

Besides, the immobilization enhances enzymes stabilities, which are much less exposed to inhibitors than the free system. But surprisingly, Aspergillus clavatus free cells had the highest extent of dye decolorization (94.9\%) compared to their immobilized cells (73.77\%). As mentioned before, the reason was due to the fungi can produce the lignin-modifying enzymes to decolorize and/or mineralize azo dyes without needing any support to enhance their action, and can also act by biosorption.

Fungal survival and growth is dependent on the ability of obtaining energy from the metabolism of substrate. The rough conditions that could be found in the industrial wastewater, could limit the survival of organisms. So it is important to combine a high efficiency treatment (Spina et al., 2012).

\section{Acknowledgement}

We sincerely thank Dr. Nourhan Mostafa for assistance in ITS2 rRNA gene regions analysis to identify fungal isolate.

\section{References}

Aruna B, Rathna Silviya L, Shiva Kumar E, Srinu A, Roja Rani P, Vijaya Lakshmi D, Durbaka (2015) Bacterial consortia for effective decolorization and bio degradation of Anthraquinone dyes. Int $\mathbf{J}$ Adv Res Biol Sci 2(11):14-21.

Bishnoi NR, Garima A (2005) Fungus An alternative for bioremediation of heavy 
metal containing wastewater: a review. Sci Ind Res (64): 93-100.

Chang JS, Chen BY, Lin YS (2004) Stimulation of bacterial decolorization of an azo dye by extracellular metabolites from Escherichia coli strain $\mathrm{NO}_{3}$. Bioresour Technol 91(3): 243-248.

Chen J, Leng J, Yang X, Liao L, Liu L, Xiao A (2017) Enhanced Performance of Magnetic Graphene Oxide-Immobilized Laccase and Its Application for the Decolorization of Dyes. Molecules 22(2): 221-232.

Chengalroyen MD, Dabbs ER (2013) The Microbial Degradation of Azo Dyes: Minireview. World J Microbiol Biotechnol 29(3):389-99.

Dawkar VV, Jadhav UU, Tamboli DP, Govindwar SP (2010) Efficient industrial dye decolorization by Bacillus sp. VUS with its enzyme system. Ecotoxicol Environ Saf. 73(7):1696-1703.

Dubey S.K, Pandey A, Bajaj AK, Misra K (2007) Some commercial azo dyes as inhibitors of mushroom tyrosinase DOPA oxidase activity. J Pharmacol Toxicol 2(8): 718-724.

Erum S, Ahmed S (2010) Comparison of dye decolorization efficiencies of indigenous fungal isolates. Afr J Biotechnol 10(17): 3399-3411.

Heravi MM, Abasion Z, Morsali A, Ardalan P, Ardalan T (2015) Biosorption of Direct red 81 dye from aqueous solution on prepared sonchus fruit plant, as a low cost biosorbent: Thermodynamic and Kinetic study. J Appl Chem 9(32):17-24.

Hossein MA, Behzad H (2012) Removal Of Reactive Red 120 And Direct Red 81 Dyes From a Queous Solutions By Pumice. Res J Chem Environ 16(1): 6268

https://www.researchgate.net/deref/http $\% 3 \mathrm{~A} \% 2$ F\%2Frefhub.elsevier.com\%2FS24682039\%2816\%2930008-5\%2Fsref16

$\mathrm{Hu}$ TL (1994) Decolourization of reactive azo dyes by transformation with Pseudomonas luteola. Bioresour Technol 49(1), 47-51.
Iqbal Z, Qureshi TM, Akhtar M, Akhtar J (2010) Evaluation of industrial effluents for reclaiming salt affected soil and achieving economic crop productivity. Soil \& Environ 29(1): 87- 90.

Jang MS, Jung BG, Sung NC, Lee YC (2007) Decolorization of textile plant effluent by Citrobacter sp. strain KCTC 18061P. J Gen Appl Microbiol 53(6): 339-43.

Junnarkar N, Murty DS, Bhatt NS, Madamwar D (2006) Decolorization of diazo dye Direct Red 81 by a novel bacterial consortium. World J Microbiol Biotechnol 22(2): 163-168.

Kadam AA, Telke AA, Jagtap SS, Govindwar SP (2011) Decolorization of adsorbed textile dyes by developed consortium of Pseudomonas sp. SUKI and Aspergillus ochraceus NCIM-1146 under solid state fermentation. J Hazard Mater 189: 486494

Kattimani L, Amena S, Nandareddy V, Mujugond P (2009) Immobilization of Streptomyces gulbargensis in Polyurethane Foam A Promising Technique for $\mathrm{L}$ Asparaginase Production. Iran J Biotechnol 7(4):199204

Kim S-Y, An J-Y, Kim B-W (2007) Improvement of the Decolorization of Azo Dye by Anaerobic Sludge Bioaugmented with Desulfovibrio desulfuricans. Biotechnol Bioprocess Eng 12(3): 222-227

Lade H, Kadam A, Paul D, Govindwar S (2015) Biodegradation and detoxification of textile azo dyes by bacterial consortium under sequential microaerophilic/aerobic processes. EXCLI J 14: 158-174

Mehta RN, Saini D (2017) Archives of Petroleum and Environmental Biotechnology Efficient Removal of Heavy metals from Oil-field Produced Water. J Pet Environ Biotechnol 2017(01): 1-11

Palanivelan R, Rajakumar S, Ayyasamy PM (2012) Exploration of Promising Dye Decolorizing Bacterial Strains Obtained from Erode and Tiruppur Textile Wastes. 
Int J Environ Sci 2(4):2470-2481

Palanivelan R, Rajakumar S, Ayyasamy PM (2014) Effect of various carbon and nitrogen sources on decolorization of textile dye remazol golden yellow using bacterial species. J Environ Biol 35: 781787

Pokharia A, Ahluwalia SS (2016) Decolorization of Xenobiotic Azo DyeBlack WNN by Immobilized Paenibacillus Alvei MTCC 10625. Int J Environ Bioremed Biodeg 4(2):35-46

Ramadan MA, Hashem AM, Al-shareef WA, Essam T (2014) Decolorization of Reactive Black 5 by Micrococcus Luteus and Candida Albicans in Wastewaters. World Appl Sci J 32(2):153-63.

Rathnan RK, Anto SM, Rajan L, Sreedevi ES Ambili M, Balasaravanan AM (2013) Comparative studies of Decolorization of Toxic Dyes with Laccase Enzymes producing Mono and Mixed cultures of Fungi. Nehru E-J 1(1): 21-24

Rogalski J, Jozwik E., Hatakka A, Leonowicz A (1995) Immobilization of laccase from Phlebia radiata on controlled porosity glass. J Mol Catal 95(1): 99-108

Sahasrabudhe MM, Saratale RG, Saratale GD, Pathade GR (2014) Decolorization and detoxification of sulfonated toxic diazo dye C.I. Direct Red 81 by Enterococcus faecalis YZ 66. J Environ Health Sci Eng 12(1): 151-163

Saratale RG, Saratale GD, Chang JS, Govindwar SP (2011) Bacterial decolorization and degradation of azo dyes: A review. J Tai Ins Chem Eng
42(1): 138-157

Shah K (2014) Biodegradation of Azo Dye Compounds. Int Res J Biochem Biotech 1(2):5-13

Spina F, Anastasi A, Prigione V, Tigini V, Varese GC (2012) Biological treatment of industrial wastewaters: a fungal approach. Chemical Engineering Transactions (27): $175-180$

Stolz A (2001) Basic and Applied Aspects in the Microbial Degradation of Azo Dyes. Appl Microbiol Biotechnol 56: 69-80

Surwase SV, Deshpande KK, Phugare SS, Jadhav JP (2013) Biotransformation studies of textile dye Remazol Orange 3R. Biotech. 3:267-275

Tobin JM, White C, Gadd GM (1994) Metal accumulation by fungi: applications in environmental biotechnology. J Ind Microbiol Biotechnol 13:126-130

Unyayar A, Mazmanci MA, Atacag H, Erkurt EA, Coral G (2005) A Drimaren Blue X3LR Dye Decolorizing Enzyme from Funalia Trogii: One Step Isolation and Identification. Enzyme Microb Technol 36(1):10-16

Vinodhkumar T, Thiripurasundari N, Ramanatha G, Karthik G (2013) Screening of Dye Degrading Bacteria from Textile Effluents. International Journal of Research and Reviews in Pharmacy and Applied Science. 3(6):84857.

Walger E, Marlin N, Molton F, Mortha G (2018): Study of the Direct Red 81 Dye/Copper(II)-Phenanthroline System. Molecules. 23 (2) 242.

\section{How to cite this article:}

Walaa A. Al-Shareef, Salwa, S.I. Afifi, Mohamed A. Ramadan and Nesma R. Sakr. 2018. Improvement of the Decolorization of Azo Dye (Direct Red 81) by Immobilized Cells of Bacillus pumilus and Free Cells of Aspergillus clavatus in Textile Waste Waters. Int.J.Curr.Microbiol.App.Sci. 7(05): 1690-1707. doi: https://doi.org/10.20546/ijcmas.2018.705.199 